\title{
HAPPINESS AND ECONOMIC DEVELOPMENT
}

In Happiness And Contemporary Society : Conference Proceedings Volume (Lviv, March, 20-21, 2021). Lviv: SPOLOM, 2021. P. 280-284. https://doi.org/10.31108/7.2021.63

ISBN 978-966-919-697-2

\section{ЩАСТЯ ТА ЕКОНОМІЧНИЙ РОЗВИТОК}

// Щастя та сучасне суспільство : збірник матеріалів міжнародної наукової конференції (Львів, 20-21 березня 2021 р.). - Львів : СПОЛОМ, 2021. С. 280-284. https://doi.org/10.31108/7.2021.63

ISBN 978-966-919-697-2 


\author{
YARMOLENKO Yuliia \\ Doctor of Sciences in Economics, Associate Professor \\ Academy of Labour, Social Relations and Tourism (Kyiv, Ukraine)
}

\title{
HAPPINESS AND ECONOMIC DEVELOPMENT
}

This article is about the relation between the concept of happiness and economic development. Today social values aimed at achieving profit, which causes a negative change in public attitudes due to their continued dominance over such qualities as justice, honesty, trust, love. Eventually, it becomes clear that such an economy has no prospects. As the only possible alternative is "Economics of happiness", in which it will be possible to equitable socio-economic development that will create opportunities to meet both material and spiritual aspects of life.

Key worlds: economy of happiness, value, emotional well-being, life satisfaction, subjective economic well-being.

\author{
ЯРМОЛЕНКО Юлія \\ доктор економічних наук, доиент \\ Академія прачі, соиіальних відносин і туризму (Київ, Україна)
}

\section{ЩАСТЯ ТА ЕКОНОМІЧНИЙ РОЗВИТОК}

В останні роки все більшої уваги потребує вивчення суб'єктивних уявлень особистості про задоволеність своїм життям та економічні чинники, що на нього впливають.

Сьогодні актуальним у теоретичному і практичному плані є розуміння тенденцій, закономірностей і чинників, що визначають стан, рівень, перспективу розвитку та шляхи забезпечення економіки щастя в Україні. Зазначені проблеми досліджували такі вітчизняні та закордонні науковці, як Р. Істерлін, Б. Стевенсон, Дж. Волферс, А. Детон, А. Канеман, Е. Освальд, Р. Винховен, О. Антипіна, Л. Родіонова, Є. Головаха, І. Несходовський, В. Дикань, І. Воловельська та ін. Але питання дослідження підходів до вимірювання щастя, зокрема на мікрорівні, досліджено ще недостатньо.

Метою статті є дослідження теоретичних і методичних аспектів економіки щастя в Україні та визначення рівня і чинників щастя на підприємстві. Адже щаслива людина - максимально ефективний працівник.

На думку американського економіста Дж. Сакса, усі суспільні цінності задіяні сьогодні в гонитві за корпоративним прибутком, яка починає домінувати над чесністю, справедливістю, довірою, фізичним і психічним здоров'ям, а також екологічною стійкістю [5]. Така ситуація може нести серйозні загрози для людського розвитку. Світ повільно приходить до усвідомлення, що сучасна економіка, заснована на збільшенні споживання і максимізації прибутку, не має перспектив, тому суспільству належить переглянути основні принципи економічного життя. Метою розвитку суспільства має бути не максимізація 
доходів, а зростання задоволеності життям кожного індивіда й підвищення рівня щастя в цілому.

Теоретичне підгрунтя економіки щастя передбачає дослідження економічних та інших факторів, що визначають людське щастя, його залежності від рівня економічного розвитку країни і визначення параметрів оцінки рівня щастя суспільства в цілому [2]. Дослідження показали, що основними факторами суб'єктивного благополуччя є: 1) життя у стабільному демократичному суспільстві, матеріальне забезпечення; 2) люблячі друзі і сім'я; 3) цікава робота i гідна оплата праці; 4) здоров'я і доступне лікування; 5) наявність життєвих цілей та власної системи цінностей; 6) філософія чи релігія, що дає сенс життя [9].

Одним з критеріїв оцінки рівня щастя можна вважати Міжнародний індекс щастя (англ. Happy Planet Index), який відображає добробут людей і стан навколишнього середовища у світі. Для його розрахунку використовують три показники: 1) вплив людини на природу; 2) тривалість життя; 3) добробут людей (задоволеність життям).

Можна сказати, що «економіка щастя» не лише відображає оптимальний баланс між потребами суспільства та обмеженими ресурсами, а й пропонує шляхи максимізації емоційного благополуччя людства.

Результати дослідження стану глобального щастя в 156-ти країнах світу щорічно подаються у Всесвітньому звіті про щастя (World Happiness Report, WHR). У звіті показано тенденції, що грунтуються на щорічних вибірках для всього світу та розподілі відповідей респондентів за чинниками щастя: 1) оцінки життя, 2) позитивного і 3) негативного впливу. Респонденти оцінюють стан свого життя за шкалою від 0 до 10 за «Шкалою самовизначення» Кантрила. Позитивний вплив включає середню частоту щастя, сміху і насолоди за попередній день, а негативний - середню частоту хвилювань, смутку і гніву за попередній день.

За даними WHR2020, рейтинг найщасливіших країн вже втретє очолила Фінляндія. Україна у рейтингу обіймає 123-тю сходинку, і це $є$ найнижчою позицією серед європейських країн, попри те, що наша країна у порівнянні 3 попереднім рейтингом піднялася на 10 сходинок [10].

Варто зазначити, що економічний добробут на макрорівні обумовлений економічним добробутом на мікрорівні. Важливим етапом у розвитку методології вимірювань економічного благополуччя стало визнання більшістю вчених (насамперед економістами) того факту, що благополуччя є суб'єктивним поняттям. 3 цього моменту прийшло розуміння, що суб'єктивні оцінки $є$ найкращим інструментом для вимірювання економічного благополуччя. На думку Еда Дінера та Роберта Бісвас-Дінера, людям найкраще самим судити про власне благополуччя і тому суб'єктивні виміри є найбільш відповідними для цієї мети [7].

На досліджуваному підприємстві «КИЇВСЬКИЙ БКК» загальний показник суб'єктивного економічного благополуччя має високий рівень. Це свідчить про достатньо високий рівень економічного оптимізму, відчуття адекватності доходу та добробуту у сім’ї, відчуття фінансового достатку, а також низький показник економічної тривоги. В економічному плані працівники вважають підприємство стабільним та таким, яке забезпечує економічні потреби своїх працівників. 
Таблиця 1.

\begin{tabular}{|c|c|c|c|c|c|c|}
\hline $\mathrm{N}=\mathbf{2 4 1}$ & Шкала & $\mathbf{M}$ & Рівень & SD & Min & Max \\
\hline професійне благополуччя & від -3 до +3 & 0,00 & середній & 0,95 & 2,76 & 1,92 \\
\hline професійна залученість & від 0 до 18 & 12,16 & середній & 3,49 & 2,1 & 18 \\
\hline автономна мотивація & від 1 до 5 & 3,63 & середній & 0,92 & 1,0 & 5 \\
\hline контрольована мотивація & від 1 до 5 & 2,53 & низький & 0,84 & 1,0 & 4,69 \\
\hline професійна затребуваність & від 47 до 280 & 210,72 & $\begin{array}{c}\text { вище } \\
\text { середнього }\end{array}$ & 26,93 & 139,0 & 276 \\
\hline $\begin{array}{l}\text { професійне психологічне } \\
\text { благополуччя }\end{array}$ & від 1 до 30 & 20,52 & середній & 2,46 & 16,44 & 27,11 \\
\hline професійне самоставлення & від 1 до 252 & 115,22 & середній & 14,79 & 86 & 149 \\
\hline психологічний капітал & від до 6 & 4,16 & $\begin{array}{c}\text { вище } \\
\text { середнього }\end{array}$ & 0,74 & 1,58 & 5,92 \\
\hline осмисленість життя & від 1 до 140 & 101,89 & середній & 19,11 & 43 & 140 \\
\hline $\begin{array}{l}\text { суб'єктивне економічне } \\
\text { благополуччя }\end{array}$ & від 1 до 6 & 4,95 & високий & 0,97 & 2,18 & 7,91 \\
\hline $\begin{array}{l}\text { суб'єктивне соціальне } \\
\text { благополуччя }\end{array}$ & від 0 до 252 & 123,91 & середній & 27,94 & 35 & 187 \\
\hline задоволеність життям & від 5 до 35 & 22,28 & середній & 5,87 & 5 & 35 \\
\hline задоволеність працею & від 19 до 95 & 67,46 & середній & 11,37 & 36 & 95 \\
\hline клімат в вашому колективі & від 13 до 65 & 47,95 & $\begin{array}{c}\text { дуже } \\
\text { високий }\end{array}$ & 9,89 & 13 & 65 \\
\hline
\end{tabular}

* N - к-сть досліджуваних; M - середнє; SD - стандартне відхилення.

Професійна залученість чи поток - стан оптимального переживання людини в контексті ії професійної діяльності, що характеризується: переживанням радості, яке виникає в момент повернення самосвідомості і суб'єктивної оцінки відповідності того, що людина робить, ії покликанню, призначенню, сенсу життя (емоційна реакція на інтерпретацію людиною зв'язку їі «Я», професійної діяльності i сенсу власного життя, призначення, як максимального наближення «Я» людини $\mathrm{i}$ того, що вона повинна робити в світі, iï місця в світі), цілеспрямованістю, свідомістю, позитивністю емоційних переживань, натхненням, відчуттям припливу енергії або відчуттям високого потенціалу до діяльності, відчуттям втрати тимчасових рамок, тотальності або повною самовіддачею на піку своїх можливостей, повним злиттям свідомості з вмістом своєї роботи.

Це доволі складний для контролю показник. На великому підприємстві 3 автоматизованими виробничими процесами, найбільш високі показники професійної залученості мають лише ті професії, які мають змогу творити, змінювати, впливати на процеси, відчувати причетність до соціально-важливих справ. Професіонал повинен відчувати, що його робота впливає на щось більше ніж він, що він залучений до важливого для його мети процесу, що саме ця професія грає важливу роль для суспільства чи значущої для нього групи людей.

Переживання потоку завжди пов'язане зі спробою вирішити складну i цікаву задачу, які є своєрідним спусковим механізмом для цього переживання. Чим більш ці задачі цікаві і складні, тим вище ймовірність потокових переживань. 
Шкала суб'єктивного щастя вимірює емоційне переживання індивідом власного життя, як цілого, що відображає загальний рівень психологічного благополуччя. На досліджуваному підприємстві показники задоволеності життям знаходяться на рівні середніх по Україні (середні показники по Україні - 21,38 балів), тобто працівники задоволені у незначному ступені. Впливати на цей показник доволі складно, тому що він відбиває процеси поза межами професійної діяльності.

Однією з умов розвитку професійної самосвідомості є задоволеність працею, яка безпосередньо пов'язана 3 мотивацією співробітників і розглядається в якості важливого людського ресурсу, що є тонким індикатором як поточного стану підприємства, так і майбутніх перспектив його розвитку.

Задоволеність працею - $\epsilon$ науковим конструктом, який частково та в загальних рисах, відбиває таке поняття, як бренд роботодавця. На досліджуваному підприємстві показники задоволеності працею середні. Але більшість професій мають дуже низькі показники, особливо це стосується кухарів-кондитерів та робітників-машиністів. Тобто бренд роботодавця потребує розробки детальної структури для кожної ключової професійної групи.

На думку Джима Лоера, основними факторами щастя є: фізичне здоров’я, розвиток та пізнання нового, допомога іншим в покращенні життя [4].

Враховуючи «фактор новизни», на підприємстві було введено низку заходів: розпочато корпоративні курси 3 вивчення англійської мови; залучено співробітників до проведення занять по програмі Excell; запроваджено Кайдзенпроекти, проект «Зелений офіс»; регулярно організовуються корпоративні поїздки; створено Бібліотеку Щастя і т. ін. Керівництво підприємства поставило за мету підвищення задоволеності роботою своїх працівників. Адже через корпоративну культуру можна впливати на рівень щастя людей та підвищувати його рівень.

Підводячи підсумок, варто зазначити, що модернізіція, економічний розвиток, зниження впливу релігії й авторитарних лідерів, поширення демократії та толерантності сприяє не лише економічному зростанню, але й зростанню рівня щастя.

Аналізуючи дані Світового дослідження цінностей, в Україні за останні 9 років відбулася Революція гідності та окупація частини Донбасу та АР Крим. Внаслідок війни відбулося значне зниження доходів населення та міграція понад мільйона внутрішньо переміщених осіб. В 2020 році в березні-травні відбувся локдаун через епідемію COVID-19, внаслідок чого багато українців втратили роботу або частину доходу. І все ж, незважаючи на всі ці потрясіння, відповідно до даних сьомої хвилі World Values Survey, в 2020 році українці почуваються в більшій безпеці, в тому числі фінансово, а також більш щасливо, ніж 9 років тому. У порівнянні з 2011 роком частка щасливих людей зросла з $68 \%$ до $78,3 \%$, частка людей з гарним здоров'ям та самооцінкою - $з$ 37\% до 45,4\%. Позитивних змін значно більше, ніж негативних, що відображає розвиток України та поступове прийняття секулярно-раціональних цінностей i цінностей самовираження. Результати опитування надають можливість на сучасному етапі осмислити місце України в ціннісно-культурному вимірі як на європейському просторі, так і в світі. I це дає розуміння щодо напрямів послідовного формування ціннісних орієнтирів на основі системи європейських цінностей, зокрема, - рівності перед законом, 
самореалізації, толерантності, відкритості змінам, індивідуальної відповідальності та взаємодопомоги. [11].

\section{ЛІТЕРАТУРА}

1. Антипина О. Экономическая теория счастья как направление научных исследований/ О. Антипина//Вопросы экономики. - 2012. - № 2. - С. 94-107.

2. Волошок О. Щастя: психологічні та економічні аспекти / О. Волошок, Л. Ноздріна // Щастя та цивілізаційний розвиток: збірник матеріалів Міжнародної науково-практичної конференції (Львів, 14-15 листопада 2019 р.). - Львів, 2019 - C. $60-64$.

3. Воробьев Е. М. Экономика счастья как новая экономическая парадигма// Воробьев Е. М. , Демченко И.

4. Лоер Дж. Стратегия счастья. - 2014.

5. Румянцева Е.Е. Экономика счастья Электронный ресурс] / Румянцева Е.Е. Режим доступа: https://cepheusbook.info/books/ekonomika-schastya

6. Сакс Дж. Экономика счастья [Электронный ресурс] / Дж. Сакс. - Режим доступа: http://www.project-syndicate.org/commentary/sachs181/Russian.

7. Diener E. Will money increase subjective well-being? / E. Diener, R. Biswas-Diener // Social Indicators Research. - 2002. - № 57. - P. 119-169.

8. Diener E. The Satisfaction With Life Scale / E. Diener, R. A. Emmons, R. J. Larsen, S. Griffin // Journal of Personality Assessment. - 1985. - № 49. - P. 71-75.

9. World Happiness Report 2019: https://worldhappiness.report/ed/2019/

10. World Happiness Report 2020: https://worldhappiness.report/ed/2020/

11. World Values Servey 2020 UA: http://ucep.org.ua/doslidzhennya/ukraine-inworld-values-survey-2020-resume-of-the-analytical-report.html 